\title{
Impact of Traumatic Dental Injuries on Oral Health-Related Quality of Life of Preschool Children and Their Families Attending a Dental Trauma Care Program
}

\author{
Ana Julia Milani $^{a} \quad$ Nathalia Fonseca Alves $^{\text {b, }}$. Tiago Martins do Espiroto-Santo ${ }^{b}$ \\ Luciana Gonçalves Ribeiro $^{\text {b }}$ Michele Mikael Ammari ${ }^{b}$ \\ Leonardo Santos Antunes $^{a}$ Lívia Azeredo Alves Antunes ${ }^{a}$ \\ a Postgraduate Program in Dentistry, School of Dentistry, Fluminense Federal University, Nova Friburgo, Brazil; \\ ${ }^{\mathrm{b} S}$ School of Dentistry, Fluminense Federal University, Nova Friburgo, Brazil; ' ${ }^{C}$ Scientific Initiation CNPq/Fluminense \\ Federal University, Nova Friburgo, Brazil
}

\section{Keywords}

Dental trauma · Quality of life · Oral health · Children ·

Family

\begin{abstract}
Background: Traumatic dental injury (TDI) constitutes a public health problem. Objective: The objective of this study was to detect the impact of TDI on oral health-related quality of life (OHRQoL) of preschool children in a dental trauma care program and to evaluate the psychometric properties of the OHRQoL instrument in this population. Methods: A cross-sectional study including a nonprobabilistic sample of 2- to 6-year-old children from a 5-year collection period was performed. We used Andreasen's classification to evaluate TDI and the Brazilian version of the Early Childhood Oral Health Impact Scale (ECOHIS) to assess OHRQoL. Based on the Kolmogorov-Smirnov test, Student's $t$ test was applied to compare the means of impact in the cases of complicated and uncomplicated TDI considering a $p$ value <0.05. Results: The final sample was composed of 146 children (mean age $4.31 \pm 1.68$ years). The search for treatment was $90 \%$ mediated and $56.7 \%$ TDI was in support of tissue. The ECOHIS had
\end{abstract}

satisfactory properties (Cronbach's $a=0.83$ and test-retest/ intraclass correlation coefficient $=0.79$ ). The ECOHIS mean was $6.79 \pm 8.64$ for the total scale, $4.29 \pm 6.46$ for the child subscale, and $2.50 \pm 3.06$ for the family subscale. Complicated TDI had a greater impact on OHRQoL in total score ( $p=$ $0.036)$, child subscale ( $p=0.038)$, symptoms domain ( $p=$ $0.049)$, and function domain $(p=0.030)$. Conclusions: The OHRQoL instrument was satisfactory. It was detected that complicated TDI impacts negatively on the OHRQoL of children and their families.

\footnotetext{
(c) 2019 The Author(s). Published by S. Karger AG, Basel on behalf of NOVA National School of Public Health
}

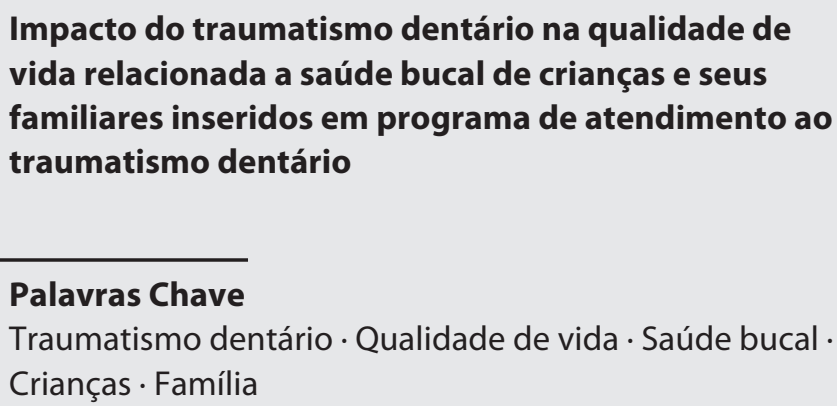

\section{KARGER}

E-Mail karger@karger.com www.karger.com/pjp

Karger

Open access (c) 2019 The Author(s). Published by S. Karger AG, Basel on behalf of NOVA National School of Public Health

This article is licensed under the Creative Commons AttributionNonCommercial-NoDerivatives 4.0 International License (CC BYNC-ND) (http://www.karger.com/Services/OpenAccessLicense) Usage and distribution for commercial purposes as well as any distribution of modified material requires written permission.
Lívia Azeredo Alves Antunes

Department of Specific Formation, School of Dentistry, Fluminense Federal University Rua Doutor Silvio Henrique Braune, 22, Centro

Nova Friburgo, RJ 28625-650 (Brazil)

E-Mail liviaazeredo@gmail.com 


\section{Resumo}

Introdução: Os traumatismos dentários (TD) constituem um problema de saúde pública. Objetivo: O objetivo deste estudo foi detectar o impacto do TD na qualidade de vida relacionada à saúde bucal (QVRSB) de crianças e seus familiares assistidos em Programa de Atendimento ao Traumatismo Dentário (PATD) e avaliar a propriedade psicométrica de um instrumento de QVRSB nessa população. Método: Um estudo do tipo transversal incluindo uma amostra não probabilística de crianças de 2-6 anos de um período de 5 anos de coleta foi realizado. Utilizouse a classificação de Andreasen para avaliar os TD e a versão brasileira do Early Childhood Oral Health Impact Scale (ECOHIS) para detectar o impacto sobre a QVRSB. Baseado no teste de Kolmogorov-Smirnov, o teste $t$ Student foi aplicado para comparar as médias de impacto nos casos de TD complicados e não complicados considerando $p<0,05$. Resultados: A amostra final contou com 146 crianças (média de idade de $4,31 \pm 1,68$ ). A busca por tratamento foi mediada em $90 \%$ dos casos e $56,7 \%$ dos TD ocorreram em tecido de suporte. O ECOHIS apresentou propriedades satisfatórias na população empregada (a de Cronbach $=0,83$ e teste-reteste/ICC $=0,79$ ). A média do ECOHIS foi $6,79 \pm 8,64$ na escala total, $4,29 \pm 6,46$ na subescala criança e 2,50 $\pm 3,06$ na subescala família. Os TD complicados apresentaram maiores escores na escala total $(p=0,036)$, subescala criança $(p=0,038)$, domínio sintoma $(p=0,049)$, domínio função $(p=0,030)$. Conclusões: $\mathrm{O}$ instrumento utilizado foi satisfatório e pode detectar que os TD complicados geraram impacto negativo na QVRSB de crianças e sua família.

C 2019 The Author(s). Published by S. Karger AG, Basel on behalf of NOVA National School of Public Health

\section{Introduction}

Traumatic dental injury (TDI) constitutes a current public health problem [1], and its risk factors as well as clinical and financial implications have been studied extensively [2-5]. It has an epidemiological relevance since it is very frequent in childhood, affecting 2 in 3 children before adulthood [6]. In Brazilian children, considering the deciduous dentition stage, it presents a prevalence ranging from 9.7 to $39.1 \%$ [7-10].

The dental aspect of health promotion and the relationship between oral health and quality of life has been the focus of dentistry professionals, mainly due to the relevance of oral problems and the physical and psychosocial impacts that it entails in the lives of children [11].
TDI acquires a special character among the causes of a negative impact on oral health-related quality of life (OHRQoL) because it has a high psychosocial impact [12-14].

In the literature, there is no specific instrument to assess TDI, so the option is to use instruments developed for children that assess OHRQoL [11]. It is essential to assess the psychometric properties of all measures to aid the investigator who wishes to use an OHRQoL measure in TDI research, as they should exhibit consistent findings and confirm the validity and reliability of this instrument and add to the aforementioned works, providing some evidence to support the psychometric properties of the OHRQoL instrument [11].

TDI has been implicated as a compromising problem in children's health and on OHRQoL, which has been investigated in several cross-sectional studies carried out in daycare centers, public/private schools, or vaccination campaign days (Table 1) [12-23]. Thus, in view of the lack of reports about the OHRQoL of preschool children attending centers of reference for TDI, the objective of this study was to evaluate the impact of TDI on the OHRQoL of preschool children and their families who seek care in a dental trauma care program (DTCP) and also to evaluate the psychometric properties of an OHRQoL instrument on this population.

\section{Subjects and Methods}

\section{Study Type and Sampling}

This study was characterized by a cross-sectional design following the guidelines recommended by Strengthening the Reporting of Observational Studies in Epidemiology [24]. A nonprobabilistic sample of records of the patients attending a DTCP from a public university in the city of Nova Friburgo, RJ, Brazil for a period of 5 years was obtained.

The municipality of Nova Friburgo has 180,016 inhabitants and acts as a specialized referral center for the eight neighboring municipalities totaling 326,782 inhabitants. Given the existing gaps related to the treatment of dentoalveolar trauma in this municipality, this project becomes relevant, since it places the university as an alternative to this assistance coverage, implementing education and prevention actions as well as favoring referencing and access of patients from this population. Still important to emphasize is the fact that the feasibility of this proposal is in line with the principle of integrality of care at all levels of complexity with professionals of various specialties.

As eligibility criteria records from 2- to 6-year-old children were included. We excluded patients' records in which the parents could not answer the questionnaire due to lack of understanding as well as questionnaires answered after 3 months of TDI. Confusing factors to detect the impact on OHRQoL were also excluded, such as the use of interceptive orthodontic appli-
Port J Public Health 2019;37:19-25 DOI: $10.1159 / 000501525$
Milani et al. 
Table 1. Association between TDI and OHRQoL from studies conducted in Brazil between 2011 and 2015 (source: PubMed database and manual search)

\begin{tabular}{|c|c|c|c|c|}
\hline Reference & $\begin{array}{l}\text { Place of sample } \\
\text { collection }\end{array}$ & Sample & Total scale & $\begin{array}{l}\text { Association } \\
\text { of TDI with } \\
\text { OHRQoL }\end{array}$ \\
\hline $\begin{array}{l}\text { Abanto et al. } \\
{[15], 2011}\end{array}$ & São Paulo/USP & $\begin{array}{l}\text { total } n=260 \\
\text { without TDI } n=182 \\
\text { with TDI } n=78\end{array}$ & $\begin{array}{l}\text { without TDI } n=9.47(10.47) \\
\text { with TDI } n=8.60(8.81)\end{array}$ & no \\
\hline $\begin{array}{l}\text { Aldrigui et al. } \\
{[16], 2011}\end{array}$ & $\begin{array}{l}\text { São Paulo/USP Screening } \\
\text { Program }\end{array}$ & $\begin{array}{l}\text { total } n=260 \\
\text { without TDI } n=173 \\
\text { with TDI } n=87\end{array}$ & $\begin{array}{l}\text { without TDI } n=9.77(10.64) \\
\text { complicated TDI } n=14.48(10.08) \\
\text { uncomplicated TDI } n=6.06(6.90)\end{array}$ & yes \\
\hline $\begin{array}{l}\text { Scarpelli et al. } \\
{[19], 2011}\end{array}$ & $\begin{array}{l}\text { Belo Horizonte/public } \\
\text { schools }\end{array}$ & $\begin{array}{l}\text { total } n=1,632 \\
\text { without TDI } n=829 \\
\text { with TDI } n=809\end{array}$ & $\begin{array}{l}\text { without TDI } n=4.17(6.65) \\
\text { with TDI } n=4.12(6.49)\end{array}$ & no \\
\hline $\begin{array}{l}\text { Viegas et al. } \\
{[17], 2012}\end{array}$ & $\begin{array}{l}\text { Belo Horizonte/daycare } \\
\text { centers }\end{array}$ & $\begin{array}{l}\text { total } n=388 \\
\text { without TDI } n=147 \\
\text { with TDI } n=241\end{array}$ & $\begin{array}{l}\text { without TDI } n=3.76(6.51) \\
\text { with TDI } n=4.02(5.82)\end{array}$ & no \\
\hline $\begin{array}{l}\text { Abanto et al. } \\
{[22], 2013}\end{array}$ & $\begin{array}{l}\text { Diadema, SP/centers on the } \\
\text { national day of vaccination }\end{array}$ & $\begin{array}{l}\text { total } n=1,215 \\
\text { without TDI } n=971 \\
\text { uncomplicated TDI } n=231 \\
\text { complicated TDI } n=13\end{array}$ & $\begin{array}{l}\text { without TDI } n=1.40(3.39) \\
\text { with TDI } n=1.23(2.60)\end{array}$ & yes \\
\hline $\begin{array}{l}\text { Kramer et al. } \\
{[20], 2013}\end{array}$ & $\begin{array}{l}\text { Campina Grande/public } \\
\text { and private schools }\end{array}$ & $\begin{array}{l}\text { total } n=1,036 \\
\text { without TDI } n=884 \\
\text { with TDI } n=152\end{array}$ & $\begin{array}{l}\text { without TDI } n=0.82(2.92) \\
\text { with TDI } n=1.42(3.89)\end{array}$ & yes \\
\hline $\begin{array}{l}\text { Siqueira et al. } \\
{[18], 2013}\end{array}$ & $\begin{array}{l}\text { Canoas/public daycare } \\
\text { centers }\end{array}$ & $\begin{array}{l}\text { total } n=814 \\
\text { without TDI } n=533 \\
\text { with TDI } n=281\end{array}$ & $\begin{array}{l}\text { without TDI } n=3.08(5.59) \\
\text { with TDI } n=3.23(5.49)\end{array}$ & yes \\
\hline $\begin{array}{l}\text { Gomes et al. } \\
{[21], 2014}\end{array}$ & $\begin{array}{l}\text { Campina Grande/public } \\
\text { and private schools }\end{array}$ & $\begin{array}{l}\text { total } n=843 \\
\text { without TDI } n=553 \\
\text { with TDI } n=286\end{array}$ & $\begin{array}{l}\text { without TDI } n=3.54(6.14) \\
\text { with TDI } n=3.71(5.95)\end{array}$ & no \\
\hline $\begin{array}{l}\text { Vieira-Andrade } \\
\text { et al. [23], } 2015\end{array}$ & $\begin{array}{l}\text { Campina Grande/public } \\
\text { and private schools }\end{array}$ & $\begin{array}{l}\text { total } n=335 \\
\text { without TDI } n=219 \\
\text { with TDI } n=116\end{array}$ & $\begin{array}{l}\text { without TDI } n=3.90(6.76) \\
\text { with TDI } n=4.10(7.04)\end{array}$ & no \\
\hline
\end{tabular}

Values for total scale are presented as mean (standard deviation). OHRQoL, oral health-related quality of life; TDI, traumatic dental injury.

ances or prostheses, the presence of active dental caries, and children with special needs (absence of motor or mental ability or with the syndrome).

\section{Data Collection}

Data about sample characterization (sex and age) and related to TDI (the type of tooth most affected; time elapsed for care search, immediate considered $<24$ h or mediate after $24 \mathrm{~h}$ ) were collected.

TDIs were recorded following the classification of Andreasen [25]: enamel fracture, enamel and dentin fracture, enamel and dentin fracture with pulp exposition, coronal and root fracture, and fractures of the supporting tissues; concussion, subluxation, lateral luxation, intrusive luxation, extrusive luxation, and avulsion. A dentist (L.A.A.A.) with experience in traumatology (gold standard) performed the clinical and radiographic examination. The clinical examination was performed under lighting, with clean and dry teeth. The radiographic examination was done using the parallelism technique with help of radiograph positioners.

The extent of TDI was classified according to levels of severity ("uncomplicated," "complicated") [26, 27], in which the individual was assigned according to injury severity as follows: (a) "uncomplicated" (those in whom the pulpal tissue was not exposed and the tooth was not dislocated); (b) "complicated" (those involving exposure of the pulpal tissue and/or tooth dislocation); (c) when the patient had more than one diagnosis included, the classification was determined by the most complicated diagnosis.

To assess the impact on OHRQoL, the Brazilian version of the Early Childhood Oral Health Impact Scale (ECOHIS) developed for 2- to 5-year-old children was applied [19]. This instrument 


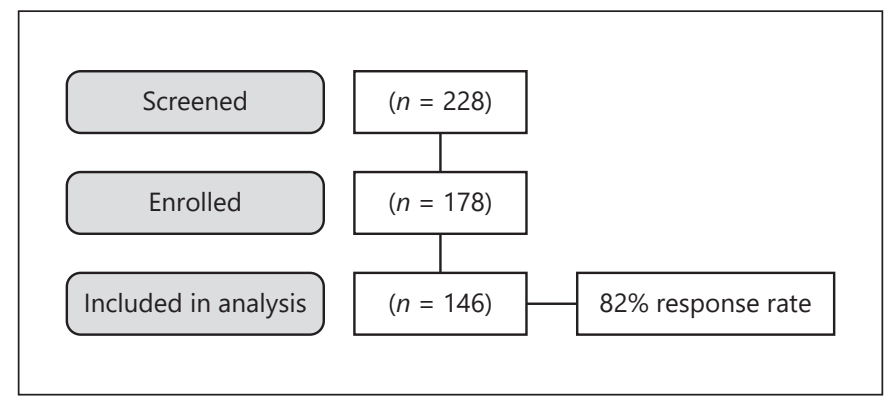

Fig. 1. Flowchart of the included sample.

evaluates the parents' perception of their child's OHRQoL. The ECOHIS consists of 13 items corresponding to four descriptive domains in the child impact section: child symptom domain (1 item), child function domain (4 items), child psychological domain (2 items), child's self-image/social interaction domain (2 items), and two domains for the family impact section: parent distress domain (2 items) and family function domain ( 2 items). The ECOHIS response categories were coded on a five-point scale: $0=$ never, 1 = hardly ever, 2 = occasionally, $3=$ often, and $4=$ very often. The scores of the ECOHIS index were calculated by summing the numeric response codes for each item. A score $>0$ accuses the presence of impact. A higher ECOHIS score indicates a negative impact on OHRQoL. A global classification of the sample was performed by three questions that dealt with oral health, general health, and general well-being. The format of the response varied by 5 points, ranging from "very good" to "very poor" for oral and general health and from "extreme" to "nothing" for well-being [19].

Instrument selection was based on the Consensus-Based Standards for the Selection of Health Status Measurement Instruments (COSMIN) checklist that was developed in an international Delphi study with the aim to provide tools for evidence-based instrument selection $[28,29]$.

OHRQoL evaluation was performed by an interview by a previously trained person who would not directly act on the child's treatment, to avoid any risk of bias in responses caused by shyness or shame, for example. The training for the use of this tool was also assisted by COSMIN [29] using a PowerPoint tutorial, and calibration was carried out in a total of $24 \mathrm{~h}$ of exercises. Interview agreement was satisfactory $(\kappa=0.90)$.

\section{Data Analysis}

The data were tabulated in a statistical program (SPSS 19.0). The Kolmogorov-Smirnov test confirmed sample normality. Thus, the means of the total scores and subscales were obtained. Student's $t$ test was applied to compare the means of impact in the cases of complicated and uncomplicated TDI considering a $p$ value $<0.05$. To ensure methodological reproducibility once our sample was 2- to 6-year-old children, the internal consistency of psychometric properties was assessed using Cronbach's $\alpha$ and test-retest reliability using the intraclass correlation coefficient. Construct validity was detected by associating scale scores with the two global indicators of the state of health (general and oral) and an indicator of well-being as a result of trauma using Pearson correlations. A pretest study in 26 parents (not part of this study) was performed
Table 2. TDI characterization

\begin{tabular}{lc}
\hline Tooth type $^{1}(n=248)$ & \\
61 & $109(43.6 \%)$ \\
51 & $98(39.2 \%)$ \\
62 & $17(6.8 \%)$ \\
52 & $16(6.4 \%)$ \\
71 & $3(1.5 \%)$ \\
81 & $2(1.0 \%)$ \\
63 & $2(1.0 \%)$ \\
53 & $1(0.5 \%)$ \\
Complexity of TDI ${ }^{2}(n=146)$ & \\
Uncomplicated & $114(78.0 \%)$ \\
Complicated & $32(22.0 \%)$ \\
TDI type - support tissue ${ }^{1}(n=137)$ & $72(29.8 \%)$ \\
Concussion & $21(8.7 \%)$ \\
Subluxation & $19(7.9 \%)$ \\
Lateral dislocation & $10(4.1 \%)$ \\
Intrusion & $1(0.4 \%)$ \\
Extrusion & $14(5.8 \%)$ \\
Avulsion & \\
TDI type - dental tissue ${ }^{1}(n=105)$ & $58(23.9 \%)$ \\
Enamel fracture & $38(15.7 \%)$ \\
Enamel/dentin fracture & $9(3.7 \%)$ \\
Fracture with pulp exposure & \\
\hline
\end{tabular}

TDI, traumatic dental injury. ${ }^{1}$ Per tooth. ${ }^{2}$ Per patient.

in order to identify the understanding of the questions and the stability of the instrument (reliability). Stability was assessed through test-retest, where the questionnaire was reapplied after 1 week. At this stage, we also evaluated the need to add some question to the quality of life evaluation questionnaires.

\section{Results}

From 228 patients who suffered TDI included in the DTCP, 178 presented TDI in the deciduous dentition. Of these, 146 achieved the inclusion criteria. This study presented $18 \%$ of loss, mainly due to incomplete records and behavior collaboration problems for the TDI clinical evaluation (Fig. 1).

The sample consisted of children with a mean age of $4.31 \pm 1.68$ years ( $54.1 \%$ boys). From 248 teeth, the most affected type were the central incisors; teeth 61 (43.6\%), teeth 51 (39.2\%). The search for treatment was $90 \%$ mediated and $56.7 \%$ TDI was in support tissue (Table 2).

The psychometric properties of the Brazilian version of the ECOHIS instrument were evaluated through internal consistency (Cronbach's $\alpha=0.83$ ), test-retest (intraclass correlation coefficient $=0,79$ ), and were considered satisfactory in this population with TDI. Construct validity was also considered satisfactory for oral health $(\rho=$ 
Table 3. Evaluation of the impact of TDI by the Brazilian version of the ECOHIS instrument: comparison of the total averages and subscales of the groups by analysis of TDI complexity

\begin{tabular}{|c|c|c|c|c|}
\hline ECOHIS (variation) scale/subscale/domain & After TDI & Uncomplicated & Complicated & $p$ value \\
\hline Total score $(0-52)$ & $6.79(8.64)$ & $6.14(7.27)$ & $9.34(8.41)$ & 0.036 \\
\hline Child subscale (0-36) & $4.29(6.46)$ & $3.92(5.66)$ & $6.34(6.05)$ & 0.038 \\
\hline Function domain $(0-16)$ & $1.72(2.91)$ & $1.75(2.82)$ & $3.03(3.17)$ & 0.030 \\
\hline Psychological domain $(0-8)$ & $0.79(1.54)$ & $0.71(1.37)$ & $0.96(1.71)$ & 0.392 \\
\hline Self-image/social interaction domain $(0-8)$ & $0.72(1.74)$ & $0.57(1.47)$ & $0.96(1.76)$ & 0.209 \\
\hline Parental distress domain $(0-8)$ & $2.02(2.41)$ & $1.78(2.28)$ & $2.31(2.64)$ & 0.272 \\
\hline Family function domain $(0-8)$ & $0.47(1.21)$ & $0.42(1.31)$ & $0.68(1.22)$ & 0.321 \\
\hline
\end{tabular}

Values are presented as mean (standard deviation). Statistical significance was determined by Student's $t$ test. ECOHIS, Early Childhood Oral Health Impact Scale; TDI, traumatic dental injury.

$0.241, p=0.003)$, general health $(\rho=0.164, p=0.047)$, child well-being $(\rho=0.522, p<0.001)$, and family wellbeing $(\rho=0.521, p<0.001)$.

The mean ECOHIS questionnaire response scores (total scale and the child/family subscales) are presented in Table 3. The mean of the total scale was $6.79 \pm 8.64$, the child subscale was $4.29 \pm 6.46$, and the family subscale was $2.50 \pm 3.06$. Complicated TDI had a greater negative impact on OHRQoL in the total score $(9.34 \pm 8.41, p=$ $0.036)$, the child subscale $(6.34 \pm 6.05, p=0.038)$, the symptom domain $(1.37 \pm 1.26, p=0.049)$, and the function domain $(3.03 \pm 3.17, p=0.030)$ (Table 3$)$.

\section{Discussion and Conclusion}

Identifying the factors that affect the OHRQoL of a population allows clinicians to prioritize actions and interventions as soon as possible [13]. It also allows not only acting on the disease, but also on the psychosocial aspect. Dentistry has an important character in systemic and local health as well as a relevant impact on the psychosocial aspect, since it is one of the main means of expressing joy through smile [11]. TDI is a public health problem [1] that occurs frequently in childhood and has great epidemiological importance [6]. In addition, TDI can cause irreparable damage to adjacent supporting structures and soft tissues, both at the time of the accident and/or after the accident [27]. The sequelae of TDI can lead to loss of the dental element. Thus, in addition to detecting the disease under clinical conditions, it is essential to implement measures that assess the psychosocial impacts caused by TDI.

Traumatic Dental Injuries and Oral

Health-Related Quality of Life
There is no specific validated instrument for the identification of the psychosocial impacts generated by TDI [11]. Thus, the instrument adopted by the present study and even by all the research accessed in the literature [1523 ] was the ECOHIS $[19,30]$, considered valid, reliable, and reproducible for the Brazilian population by some studies. However, even though it has already been used, in the present research, we also included 6-year-old children so the psychometric properties were checked. Following the COSMIN guidelines [28, 29], the psychometric properties of the instrument for TDI application were proven. It was also observed that it was valid and reliable with satisfactory internal validity, construct validity, and good understanding.

The studies carried out by Abanto et al. [15] and Aldrigui et al. [16] presented high scores of TDI in the total scale, child subscale, and family subscale when compared with the present study. Aldrigui et al. [16] detailed the research to relate the type and severity of the trauma, and the results showed that complicated dental trauma generates a greater negative impact on the OHRQoL of children and their families corroborating with our study. However, other research presented averages of impact on the total scale and subscales smaller than what was found in the present work [17-23] (Table 1).

With regard to the place of sample collection, the studies carried out by Viegas et al. [17], Kramer et al. [20], Scarpelli et al. [19], Siqueira et al. [18], Gomes et al. [21], and Vieira-Andrade et al. [23] were in public/private daycare centers/schools. In the study by Aldrigui et al. [16], the children were selected through the screening program of a public university, and Abanto et al. [15] conducted their study in health centers on the national day of vac-

Port J Public Health 2019;37:19-25 
cination. Jesus et al. [10] assessed the prevalence of TDI in children aged 0-6 years attending a dentoalveolar traumatism reference center, and Fariniuk et al. [30] evaluated cases of TDI treated at the Dentoalveolar Trauma Care Service. However, both Jesus et al. [10] and Fariniuk et al. [31] did not evaluate the impact of TDI on OHRQoL, so they did not encompass all aspects of the concept of health.

The impact of TDI on OHRQoL in the context of dental care programs had already been evaluated through the perception of parents/caregivers of the oral health of their children/adolescents (Antunes et al. [27]) and on the family impacts (Antunes et al. [32]). Thus, the present study is the first to evaluate the negative impact on the OHRQoL in preschool children. Thus, this study is of great relevance since the DTCP is a reference center of the region, facilitating direct preventive actions as well as the management of patient with a more humanized and holistic view. Therefore, this research was extremely sensitive to evaluate the negative impact that TDI generates on children's OHRQoL.

According to some authors (Abanto et al. [15], Viegas et al. [17], Scarpelli et al. [19], Gomes et al. [21], VieiraAndrade et al. [23]), the OHRQoL of children and their families was not influenced by TDI. This may be attributed to the fact that the most common type of TDI evaluated by them was uncomplicated TDI [14]. However, in the study by Aldrigui et al. [16] and in the present study, in which both complicated and uncomplicated TDI were evaluated, it was observed that complicated TDI had a negative impact on the OHRQoL of preschool children.

The present study has some limitations. For a better comprehension of results and associations, it is extremely important to carry out further studies using larger samples or in other referencing centers for TDI in preschool children to confirm or refute the present results. In addition, the impact evaluation after TDI treatment to detect whether OHRQoL was improved would be of great relevance.
Based on the validity and reliability of the instrument of OHRQoL applied, it can be stated that TDI has a negative impact on children's OHRQoL, mainly those complicated. Thus, the present study is extremely relevant in the evaluation of the negative impact of TDI in the OHRQoL of young children and their families, supporting clinicians and health professionals in the planning and decision-making process. In addition, it emphasizes the need for DTCPs to provide care to the population.

\section{Acknowledgements}

The authors are indebted to the participants of the study. N. Fonseca Alves and A.J. Milani were supported by the Brazilian Program for Scientific Initiation/the National Scientific and Technological Development Council - PIBIC/CNPq).

\section{Statement of Ethics}

The present study was approved (\#274/2010) by the Local Research Ethics Committee. Written authorization from the parent or legal guardian of the child included in the sample of the present survey was obtained.

\section{Disclosure Statement}

The authors declare no potential conflicts of interest with respect to the authorship and/or publication of this article.

\section{Author Contributions}

All authors contributed to this work. L.A. Alves Antunes and L.S. Antunes wrote the first and the final draft of the manuscript. A.J. Milani, N. Fonseca Alves, and T. Martins do Espiroto-Santo collected the data. A.J. Milani and L.A. Alves Antunes realized data management. A.J. Milani, N. Fonseca Alves, T. Martins do Espiroto-Santo, and L. Gonçalves Ribeiro wrote the paper. M.M. Ammari, L.A. Alves Antunes, and L.S. Antunes critically reviewed the final draft of the paper.

\section{References}

1 Petersen PE, Bourgeois D, Ogawa H, Estupinan-Day S, Ndiaye C. The global burden of oral diseases and risks to oral health. Bull World Health Organ. 2005 Sep;83(9):661-9.

2 Hamilton FA, Hill FJ, Holloway PJ. An investigation of dento-alveolar trauma and its treatment in an adolescent population. Part 1: the prevalence and incidence of injuries and the extent and adequacy of treatment received. Br Dent J. 1997 Feb;182(3):91-5.
3 Glendor U, Jonsson D, Halling A, Lindqvist $\mathrm{K}$. Direct and indirect costs of dental trauma in Sweden: a 2-year prospective study of children and adolescents. Community Dent Oral Epidemiol. 2001 Apr;29(2):150-60.

4 Feldens CA, Borges TS, Vargas-Ferreira F, Kramer PF. Risk factors for traumatic dental injuries in the primary dentition: concepts, interpretation, and evidence. Dent Traumatol. 2016 Dec;32(6):429-37.
5 Soares TR, Magno MB, Jural LA, Loureiro JM, Chianca TK, de Andrade Risso P, et al. Risk factors for traumatic dental injuries in the Brazilian population: A critical review. Dent Traumatol. 2018 Dec;34(6):445-54.

6 Andreasen JO, Lauridsen E, Daugaard-Jensen J. Dental traumatology: an orphan in pediatric dentistry? Pediatr Dent. 2009 Mar-Apr; 31(2):153-6. 
7 Cardoso M, de Carvalho Rocha MJ. Traumatized primary teeth in children assisted at the Federal University of Santa Catarina, Brazil. Dent Traumatol. 2002 Jun;18(3):129-33.

8 Ferreira JM, Fernandes de Andrade EM, Katz CR, Rosenblatt A. Prevalence of dental trau$\mathrm{ma}$ in deciduous teeth of Brazilian children. Dent Traumatol. 2009 Apr;25(2):219-23.

9 Robson F, Ramos-Jorge ML, Bendo CB, Vale MP, Paiva SM, Pordeus IA. Prevalence and determining factors of traumatic injuries to primary teeth in preschool children. Dent Traumatol. 2009 Feb;25(1):118-22.

10 Jesus MA, Antunes LA, Risso PA, Freire MV, Maia LC. Epidemiologic survey of traumatic dental injuries in children seen at the Federal University of Rio de Janeiro, Brazil. Braz Oral Res. 2010 Jan-Mar;24(1):89-94.

11 Antunes LA, Leão AT, Maia LC. The impact of dental trauma on quality of life of children and adolescents: a critical review and measurement instruments. Cien Saude Colet. 2012 Dec;17(12):3417-24. Portuguese.

12 Cortes MI, Marcenes W, Sheiham A. Impact of traumatic injuries to the permanent teeth on the oral health-related quality of life in 12-14-year-old children. Community Dent Oral Epidemiol. 2002 Jun;30(3):193-8.

13 Ramos-Jorge ML, Bosco VL, Peres MA, Nunes AC. The impact of treatment of dental trauma on the quality of life of adolescents - a case-control study in southern Brazil. Dent Traumatol. 2007 Apr;23(2):114-9.

14 Fakhruddin KS, Lawrence HP, Kenny DJ, Locker D. Impact of treated and untreated dental injuries on the quality of life of Ontario school children. Dent Traumatol. 2008 Jun; 24(3):309-13

15 Abanto J, Carvalho TS, Mendes FM, Wanderley MT, Bönecker M, Raggio DP. Impact of oral diseases and disorders on oral health-related quality of life of preschool children. Community Dent Oral Epidemiol. 2011 Apr; 39(2):105-14

16 Aldrigui JM, Abanto J, Carvalho TS, Mendes FM, Wanderley MT, Bönecker M, et al. Im- pact of traumatic dental injuries and malocclusions on quality of life of young children. Health Qual Life Outcomes. 2011 Sep;9(1): 78.

17 Viegas CM, Scarpelli AC, Carvalho AC, Ferreira FM, Pordeus IA, Paiva SM. Impact of traumatic dental injury on quality of life among Brazilian preschool children and their families. Pediatr Dent. 2012 Jul-Aug;34(4): 300-6.

18 Siqueira MB, Firmino RT, Clementino MA, Martins CC, Granville-Garcia AF, Paiva SM. Impact of traumatic dental injury on the quality of life of Brazilian preschool children. Int J Environ Res Public Health. 2013 Nov;10(12): 6422-41.

19 Scarpelli AC, Oliveira BH, Tesch FC, Leão AT, Pordeus IA, Paiva SM. Psychometric properties of the Brazilian version of the Early Childhood Oral Health Impact Scale (BECOHIS). BMC Oral Health. 2011 Jun; 11(Jun):19.

20 Kramer PF, Feldens CA, Ferreira SH, Bervian J, Rodrigues PH, Peres MA. Exploring the impact of oral diseases and disorders on quality of life of preschool children. Community Dent Oral Epidemiol. 2013 Aug;41(4):32735.

21 Gomes MC, Pinto-Sarmento TC, Costa EM, Martins CC, Granville-Garcia AF, Paiva SM. Impact of oral health conditions on the quality of life of preschool children and their families: a cross-sectional study. Health Qual Life Outcomes. 2014 Apr;12(1):55.

22 Abanto J, Tsakos G, Paiva SM, Goursand D, Raggio DP, Bönecker M. Cross-cultural adaptation and psychometric properties of the Brazilian version of the scale of oral health outcomes for 5-year-old children (SOHO-5). Health Qual Life Outcomes. 2013 Feb;11(1): 16.

23 Vieira-Andrade RG, Siqueira MB, Gomes GB, D'Avila S, Pordeus IA, Paiva SM, et al. Impact of traumatic dental injury on the quality of life of young children: a case-control study. Int Dent J. 2015 Oct;65(5):261-8.
24 von Elm E, Altman DG, Egger M, Pocock SJ Gøtzsche PC, Vandenbroucke JP; STROBE Initiative. The Strengthening the Reporting of Observational Studies in Epidemiology (STROBE) statement: guidelines for reporting observational studies. J Clin Epidemiol. 2008 Apr;61(4):344-9.

25 Andreasen JO, Andreasen FM. Textbook and color atlas of traumatic injuries to the teeth, 3rd ed. Copenhagen: Munksgaard; 2003.

26 Glendor U, Halling A, Andersson L, EilertPetersson. Incidence of traumatic tooth injuries in children and adolescents in the county of Västmanland, Sweden. Swed Dent J. 1996; 20(1-2):15-28.

27 Antunes LA, Luiz RR, Leão AT, Maia LC. Initial assessment of responsiveness of the P-CPQ (Brazilian Version) to describe the changes in quality of life after treatment for traumatic dental injury. Dent Traumatol. 2012 Aug;28(4):256-62.

28 Mokkink LB, Terwee CB, Patrick DL, Alonso J, Stratford PW, Knol DL, et al. The COSMIN checklist for assessing the methodological quality of studies on measurement properties of health status measurement instruments: an international Delphi study. Qual Life Res. 2010 May;19(4):539-49.

29 Paiva SM, Perazzo MF, Ortiz FR, Pordeus IA, Martins-Júnior PA. How to Select a Questionnaire with a Good Methodological Quality? Braz Dent J. 2018 Jan-Feb;29(1):3-6.

30 Tesch FC, Oliveira BH, Leão A. Semantic equivalence of the Brazilian version of the Early Childhood Oral Health Impact Scale. Cad Saude Publica. 2008 Aug;24(8):1897909. Portuguese.

31 Fariniuk LF, Souza MH, Westphalen VP, Carneiro E, Silva Neto UX, Roskamp L, et al. Evaluation of care of dentoalveolar trauma. J Appl Oral Sci. 2010 Jul-Aug;18(4):343-5.

32 Antunes LA, Antunes LS, Luiz RR, Leão AT, Maia LC. Assessing the responsiveness of the Brazilian FIS to treatment for traumatic dental injury. Community Dent Oral Epidemiol. 2013 Dec;41(6):551-7.
Traumatic Dental Injuries and Oral Health-Related Quality of Life
Port J Public Health 2019;37:19-25

DOI: $10.1159 / 000501525$ 